\title{
Contemporary antiviral drug regimens for the prevention and treatment of orolabial and anogenital herpes simplex virus infection in the normal host: Four approved indications and 13 off-label uses
}

\author{
Fred Y Aoki MD
}

\begin{abstract}
FY Aoki. Contemporary antiviral drug regimens for the prevention and treatment of orolabial and anogenital herpes simplex virus infection in the normal host: Four approved indications and 13 off-label uses. Can J Infect Dis 2003;14(1):17-27.

Herpes simplex virus (HSV) orolabial and anogenital infection causes substantial and recurring disease in healthy individuals due directly to infection of these sites and, indirectly, due to its complications. These complications include eczema herpeticum plus erythema multiforme and neonatal HSV infection, respectively. Four drugs: acyclovir, famciclovir, valacyclovir and penciclovir, are currently licensed by the Therapeutics Products Directorate of Health Canada for the management of HSV infections. Although these drugs are only approved for four orolabial and anogenital infections in healthy persons, their efficacy and safety for 13 other related uses in this population have been demonstrated in controlled clinical trials, so called off-label uses. In this review, the evidence supporting these 17 uses, the drugs and regimens evaluated, and their current costs, are described.
\end{abstract}

Key Words: Antiviral therapy; Herpes simplex virus infection; Prophylaxis

\section{Posologies actuelles de médicaments antiviraux pour la prévention et le traitement d'infections bucco-labiales et ano-génitales au virus de l'herpès simplex chez des hôtes normaux : quatre indications approuvées et treize utilisations non indiquées sur l'étiquette}

\begin{abstract}
RÉSUMÉ : Les infections bucco-labiales et ano-génitales au virus de l'herpès simplex (HSV) sont cause directe, par les foyers eux-mêmes, et indirecte, par leurs complications, d'affections sérieuses et récurrentes chez des personnes en bonne santé. Parmi les complications figurent l'eczéma herpétiforme, l'érythème polymorphe et les infections du nouveau-né au HSV. La Direction des produits thérapeutiques de Santé Canada a autorisé l'utilisation de quatre médicaments, soit l'acyclovir, le famciclovir, le valacyclovir et le penciclovir, pour le traitement des infections au HSV. Même si leur emploi n'a été approuvé que pour quatre types d'infection, buccolabiale et ano-génitale, chez des personnes en bonne santé, leur efficacité et leur innocuité pour 13 autres utilisations connexes dans la même population ont été démontrées dans des essais cliniques comparatifs; c'est ce qu'on appelle les utilisations non indiquées sur l'étiquette. Le présent article de synthèse expose les données à l'appui des 17 utilisations en question, les médicaments évalués et leurs posologies ainsi que les coûts actuels.
\end{abstract}

Table 1 lists the four indications for which these drugs have been approved by the TPD and the 13 off-label uses, which have been proved in one or more placebo controlled clinical trials.

The data pertaining to these uses follow.

\section{APPLIED CLINICAL PHARMACOKINETICS AND MOLECULAR PHARMACOLOGY}

Selected aspects of the clinical and molecular pharmacology of the antiviral drugs have therapeutic implications. First, the enhanced oral bioavailability of PCV and ACV from their respective prodrugs, FCV and VCV, has made it possible to achieve therapeutic results comparable with those obtained with two to five times a day oral ACV using once daily to thrice daily schedules. The absolute bioavailability of ACV from ACV and VCV tablets and PCV from FCV tablets averages $15 \%$ to $30 \%(1), 55 \%(2)$ and $77 \%$ (3), respectively. Incomplete ACV absorption from the upper intestine is due in part to a saturable process (4). The percentage of drug absorbed

Departments of Medicine, Medical Microbiology, Pharmacology and Therapeutics, University of Manitoba, Winnipeg, Manitoba

Correspondence and reprints: Dr Fred Y Aoki, Departments of Medicine, Medical Microbiology, Pharmacology and Therapeutics, Univeristy of Manitoba, Basic Medical Sciences Building, Room 510, 730 William Avenue, Winnipeg, Manitoba R3E OW3. Telephone 204-789-3625,

fax 204-789-3926, e-mail nelsonak@ms.umanitoba.ca 
TABLE 1

Therapeutic Products Directorate (TPD) of Health Canada approved and off-label indications for oral and topical antiherpes drugs in Canada, 2002

\begin{tabular}{|c|c|}
\hline Indication & Drugs and formulation \\
\hline \multicolumn{2}{|l|}{ Approved indications } \\
\hline Cold sores - therapy & Penciclovir cream \\
\hline \multicolumn{2}{|l|}{ Genital herpes - therapy } \\
\hline First episode & Acyclovir tablets, cream and ointment, injectable \\
\hline \multicolumn{2}{|l|}{ Recurrent } \\
\hline Episode therapy & Acyclovir, famciclovir and valacyclovir tablets \\
\hline Suppressive therapy: adults, nonpregnant & Acyclovir, famciclovir and valacyclovir tablets \\
\hline \multicolumn{2}{|l|}{ Off-label indications ${ }^{*}$} \\
\hline \multicolumn{2}{|l|}{ Orolabial herpes } \\
\hline \multicolumn{2}{|l|}{ Gingivostomatitis } \\
\hline Therapy & Acyclovir suspension \\
\hline Prophylaxis in children in daycare & Acyclovir tablets \\
\hline \multicolumn{2}{|l|}{ Recurrent cold sores } \\
\hline Episode therapy & Acyclovir tablets, cream and ointment \\
\hline Suppressive therapy & Acyclovir tablets and cream, valacyclovir tablets \\
\hline \multicolumn{2}{|l|}{ Prophylaxis } \\
\hline After trigeminal nerve surgery & Acyclovir tablets \\
\hline During sun exposure & Acyclovir cream, tablets \\
\hline Recurrent erythema multiforme prevention & Acyclovir tablets \\
\hline Eczema herpeticum - therapy & Acyclovir tablets \\
\hline \multicolumn{2}{|l|}{ Genital herpes - therapy } \\
\hline First episode & Valacyclovir and famciclovir tablets \\
\hline \multicolumn{2}{|l|}{ Recurrent } \\
\hline Short course therapy of 2 to 3 days & Acyclovir and valacyclovir, respectively \\
\hline \multicolumn{2}{|l|}{ Suppressive therapy } \\
\hline Recurrent disease in pregnant women & Acyclovir tablets \\
\hline Asymptomatic shedding in nonpregnant women & Acyclovir tablets \\
\hline Herpes proctitis - therapy & Acyclovir tablets \\
\hline
\end{tabular}

${ }^{*}$ Off-label use proved in one or more controlled clinical trials

declined from $20 \%$ from a $200 \mathrm{mg}$ tablet (1) to $12 \%$ from an $800 \mathrm{mg}$ tablet (2). VCV is better absorbed than ACV due to an active stereoselective transporter in the intestinal brush border membrane (5). The extent of absorption averages 55\% and is independent of dose. After absorption, VCV undergoes hydrolysis during first-pass through the liver so that only ACV appears in the systemic circulation (6). A mean of $77 \%$ of PCV is bioavailable from oral FCV doses ranging from $125 \mathrm{mg}$ to $750 \mathrm{mg}$. After absorption, FCV is extensively metabolized by oxidation and deacetylation in intestinal epithelial cells and hepatocytes to PCV (7). Food does not affect the oral bioavailability of ACV, VCV or FCV.

The second point of clinical relevance concerning the pharmacology of ACV and PCV relates to their intracellular processing as prodrugs. They are nucleoside analogues without antiviral activity until they are converted to nucleotidetriphosphate moieties within HSV-infected cells. The initial and critical step is effected through conversion to the nucleotide-monophosphate form by the virus-encoded enzyme, thymidine kinase (TK) $(8,9)$. This initial phosphorylation step prevents diffusion out of the cell, resulting in the accumulation of nucleotides in HSV-infected cells. This has the dual effect of increasing the drug concentration in cells where it is required and minimizing the drug concentration and, hence, the potential risk of adverse effects in other uninfected cells.
Genomic mutation resulting in the loss of $\mathrm{TK}$ activity $\left(\mathrm{TK}^{-}\right)$ is associated with the emergence of ACV-resistance and is the commonest mechanism for the loss of susceptibility (10). Not unexpectedly, such ACV-resistant HSV mutants are crossresistant to PCV. Fortunately, the emergence of ACV-resistant mutants has been almost completely limited to situations in which ACV is administered for prolonged periods to immunocompromised hosts, such as those with HIV infection (11). Recently, case reports of the development of clinically aggressive ACV-resistant infection due to $\mathrm{TK}^{-}$strains (12) have raised concerns about the possibility that new HSV infections in normal hosts in the future will be caused by ACV- (and PCV-) resistant strains of HSV with attendant treatment failure.

Effective, safe treatments have now been described for initial and recurrent orolabial and anogenital HSV infection in immunocompetent individuals and some of their complications. We review herewith TPD approved indications for treatment of these infections as well as off-label uses that have been demonstrated in controlled clinical trials.

\section{Primary gingivostomatitis}

\section{OROLABIAL HSV}

Therapy: No antiviral drugs are licensed for the prevention or treatment of primary HSV gingivostomatitis in healthy children. However, gingivostomatitis of mild to moderate severity 
that does not preclude oral intake can be effectively and safely treated with oral ACV suspension. In two placebo controlled randomized trials, ACV treatment $(15 \mathrm{mg} / \mathrm{kg}$ five times per day for seven days [13] or $600 \mathrm{mg} / \mathrm{m}^{2}$ four times daily for 10 days [14]) accelerated the resolution of orolabial symptoms and signs by $50 \%$ to $80 \%$, fever by $65 \%$ (13) and viral shedding from a median duration of five days to one day (13) or 10 days to four days (14). Tolerance measured by the incidence of adverse effects was good in both studies, as was adherence. Safety reflected in an absence of changes in blood chemistry and hematological parameters was not different between ACV and placebo recipients (14), nor was the recurrence rate to one year of follow-up (14). Further studies are required to define the optimal dose and duration of therapy for such children as well as an approach for treating children with severe disease that precludes swallowing. Until such time, clinicians, nevertheless, can prescribe these oral regimens for most paediatric patients; for children with severe disease precluding oral therapy, intravenous ACV would appear to be a logical recommendation, but such a strategy has not been validated in a controlled trial.

Prophylaxis: An outbreak of primary HSV gingivostomatitis in young children in a day-care nursery has been successfully prevented by oral ACV prophylaxis. When the first case was diagnosed, prophylaxis of 53 unaffected children with crushed oral ACV tablets 30 to $60 \mathrm{mg} / \mathrm{kg}$ daily in three to five doses for seven days was completely effective in preventing gingivostomatitis. Disease developed in $82 \%$ of 22 untreated control children (15). ACV suspension (vide supra) could probably replace the crushed tablets used in this study, although the oral bioavailability of ACV from suspension appears to be lower than that from tablets (16).

\section{Recurrent orolabial infection}

Recurrent orolabial HSV infection (cold sores) can be managed by treating each recurrence (episode therapy) or by preventing recurrent disease by the continuous ingestion of drugs (suppressive therapy).

Episode therapy: Treatment of recurrent cold sores with topical $5 \% \mathrm{ACV}$ in a polyethylene glycol ointment base initiated during the prodromal phase (17) or within $8 \mathrm{~h}$ of the first symptoms or sign of a recurrence yielded limited and inconsistent therapeutic effects (18). On the other hand, treatment with 5\% ACV in a polypropylene glycol cream formulation produced a modest but statistically significant reduction in healing time, albeit without reductions in pain and/or itching (19). The improvement was ascribed to better penetration of ACV from the cream than the ointment formulation into the basal layers of the epidermis where HSV replication is occurring.

Initiating treatment even earlier with oral ACV and, most recently, topical PCV has yielded better results. Initiation of therapy within $1 \mathrm{~h}$ of the first symptom or sign of recurrent herpes labialis with oral ACV $400 \mathrm{mg}$ five times per day for five days alleviated some manifestations of the infection (20). In the subgroup of subjects who initiated treatment in the prodromal or erythema stage, median pain duration was reduced by $34 \%$ (from 2.9 days to 1.9 days) and median healing time by 26\% (from 8.0 days to 5.9 days). No benefit was observed in individuals whose cold sores were in the papular or vesicular stage at the time of initiation of treatment. Mean duration of
HSV shedding in the $31 \%$ of volunteers who were virus culture-positive was not different between the groups. Recently, the same therapeutic strategy was used in two large controlled trials (total subjects 3057) comparing the therapeutic efficacy and safety of $1 \%$ topical PCV cream $(\mathrm{n}=1516)$ and its vehicle $(\mathrm{n}=1540)$ as placebo (21). PCV or placebo cream was applied within $1 \mathrm{~h}$ of the onset of symptoms or signs of a cold sore and for six times the first day and every $2 \mathrm{~h}$ while awake for a further three days (total four days). Uniform and consistent significant subjective and objective therapeutic effects were observed in subjects with both early (prodrome or erythema stage lesions) or later stage lesions (papule or vesicular cold sore). Median time to loss of pain, time to healing and duration of HSV shedding was reduced in the combined studies by $22 \%$ to $35 \%$ in the PCV recipients. PCV-treated patients in the early lesion subgroup ceased shedding virus faster than the placebo recipients, but no difference was observed between treatment groups who had late stage lesions at the time of treatment initiation. Both oral ACV and topical PCV were well tolerated compared with the corresponding placebo. To achieve these therapeutic effects, it is apparent that patients need to literally carry their medication with them in order to initiate treatment within $1 \mathrm{~h}$ of the appearance of symptoms or signs of a cold sore. Delaying the start of oral ACV therapy for $8 \mathrm{~h}$ has yielded inconsistent results; the impact of a delay from 2 to $7 \mathrm{~h}$ has not been reported. Topical 1\% PCV cream has been approved by the TPD for cold sore treatment but is not yet marketed for this use. There have not been any reports of the comparative benefits of topical PCV versus an oral antiherpes drug.

Suppressive therapy: An alternative to early treatment of recurrent herpes labialis is the prevention of the development of cold sores by suppressive oral ACV or oral VCV used offlabel. In a double-blind, randomized crossover study, otherwise healthy adults with a history of six or more episodes of cold sores per year were treated with oral ACV 400 mg twice daily or placebo for four months (22). ACV reduced clinically- and virologically-confirmed recurrences by $53 \%$ and $71 \%$, respectively, compared with placebo therapy. A comparable result with a 77\% reduction in clinically diagnosed recurrences was observed during suppression with oral ACV $200 \mathrm{mg}$ four times daily in a double-blind crossover trial (23). Oral VCV $500 \mathrm{mg}$ once daily for four months increased the time to the first recurrence of cold sores from an average of 10.6 weeks in placebo recipients to 16.7 weeks $(\mathrm{P}=0.005)$ (24). VCV tended to reduce the number of recurrences from $70 \%$ to $35 \%$ $(\mathrm{P}=0.056)$. It was well tolerated compared with placebo. The data suggest that VCV $500 \mathrm{mg}$ once daily suppresses recurrent cold sores in healthy adults (24). Collectively, these results suggest that oral ACV and VCV are efficacious for prophylaxis of recurrent herpes labialis.

Prevention of cold sores after trigeminal nerve surgery or during sun exposure: Prophylactic oral ACV is effective for at least two other off-label indications. In otherwise healthy adults undergoing elective surgery for trigeminal neuralgia, recurrent herpes labialis is observed in 38\% to $94 \%$ of patients postoperatively. Oral ACV $400 \mathrm{mg}$ twice daily started on the evening before surgery and continued for a total of five days reduced the incidence of cold sore from $81 \%$ in placebo recipients to $21 \%$ (a $74 \%$ reduction) (25). In adults with a history 
of sun-induced herpes labialis, oral ACV 400 mg twice daily begun $12 \mathrm{~h}$ before sun exposure combined with frequent sunscreen use reduced the incidence of cold sore by $74 \% \mathrm{com}-$ pared with placebo therapy during seven days of treatment (26). Using a similar short term prophylaxis approach with topical ACV, Raborn et al (27) reported that ACV 5\% cream applied $2 \mathrm{~h}$ before sun exposure in adult skiers and five times during the day for seven days reduced the frequency of cold sore from $43 \%$ in placebo recipients to $23 \%$ in ACV recipients, a $47 \%$ reduction. In a longer, 16-week, double-blind, crossover trial, adults with herpes labialis recurring six or more times per year were treated with $5 \% \mathrm{ACV}$ cream or placebo (28). Cream was applied four times daily to any area previously affected by cold sores as well as any area where prodromal symptoms of recurrent herpes labialis developed during the study. Doctor-diagnosed cold sores were significantly reduced from a mean of 1.1 per subject during 16 weeks of placebo treatment to 0.5 during ACV therapy, a $45 \%$ reduction. The mean number of days when cold sores were present was significantly reduced by $24 \%$, from 12.4 to 9.5 in the two groups, respectively.

Eczema herpeticum therapy: HSV infection of eczematous skin, often of the facial area, can complicate orolabial herpes infection and cause extensive local disease. Oral ACV was nearly twice as effective as placebo for the treatment of eczema herpeticum (29). In a double-blind, placebo controlled trial, 32 patients were treated with ACV $200 \mathrm{mg}$ tablets or placebo tablets ( $\mathrm{n}=28$ ), both five times per day for five days. A significantly higher percentage of ACV recipients improved, beginning at day four (81\%), compared with placebo recipients $(43 \%)$. No differences in adverse symptoms were reported.

Prevention of recurrent erythema multiforme: Another offlabel indication for oral ACV is the prevention of recurrent erythema multiforme (REM). REM is reported to be preceded by recurrent herpes labialis in up to $71 \%$ of cases (30). Uncontrolled observations suggested that oral ACV therapy with $200 \mathrm{mg}$ five times per day for five days initiated at the first sign of cold sore or REM was effective in only $11 \%$ of cases, which may not be different from a placebo effect (30). However, suppressive oral ACV is effective in preventing REM, whereas early treatment of recurrent cold sore or REM does not appear to be effective (30). Oral ACV $400 \mathrm{mg}$ twice daily during 26 weeks of prophylaxis reduced REM by $86 \%$, from 3.7 to 0.5 in placebo recipients $(P=0.0004)$ (31). This paralleled the reduction in recurrent herpes labialis of $71 \%$, from 2.1 to 0.9. When ACV prophylaxis failed, REM was as severe in ACV-treated subjects as in placebo-treated subjects.

\section{GENITAL HERPES}

The pharmacological therapy of genital herpes $(\mathrm{GH})$ produces beneficial effects ranging from modest to dramatic.

\section{First-episode genital infection}

Severe primary GH infection, whether due to HSV type-1 (HSV-1) or HSV type-2 (HSV-2), is characterized by extensive genital lesions, systemic symptoms, complications and a protracted course that can last for 35 days (32). Nonprimary first $\mathrm{GH}$ infections are generally less severe. Both types of initial genital infection are markedly benefited by antiviral thera- py. Topical, intravenous and oral ACV have all been shown to be efficacious and safe compared with the corresponding placebo formulation for treatment of first episodes of $\mathrm{GH}$ in the immunocompetent host and all are approved for this indication in Canada. Although no direct comparisons of the three ACV formulations have been conducted, an analysis of results from placebo controlled ACV treatment trials limited to patients with primary $\mathrm{GH}$, by Corey et al (33), strongly suggests that systemic therapy with oral or intravenous $\mathrm{ACV}$ produces more marked clinical and antiviral effects than does topical ACV. Practical considerations have resulted in the preference for oral ACV as the treatment of choice for most immunocompetent individuals with first-episode GH. The approved dose is $200 \mathrm{mg}$ five times per day for five to 10 days as demonstrated by Mertz et al (34). A higher dose of oral $\mathrm{ACV}, 800 \mathrm{mg}$ five times per day, yielded no greater benefit than the recommended dose and tended to cause more adverse gastrointestinal symptoms than the lower dose (35). Treatment is effective when initiated up to seven days after the onset of lesions, in part because of the protracted course of more severe infections. The addition of topical 5\% ACV therapy to oral ACV treatment did not yield better results than oral ACV alone (36). For patients unable to take oral ACV, therapy may be started with intravenous treatment of $5 \mathrm{mg} / \mathrm{kg}$ infused over 60 min every $8 \mathrm{~h}$ and then converted to oral therapy when practicable.

Recently, the efficacy and safety of FCV and VCV compared with oral ACV $200 \mathrm{mg}$ five times per day in immunocompetent adults with first-episode $\mathrm{GH}$ has been reported. Results of therapy with FCV $125 \mathrm{mg}$ to $750 \mathrm{mg}$ thrice daily have been described $(37,38)$. In one study, subjects with primary and nonprimary first-episode $\mathrm{GH}$ of five days duration or less were randomized to therapy with FCV $750 \mathrm{mg}$ thrice daily $(\mathrm{n}=38)$ or oral ACV $200 \mathrm{mg}$ five times per day $(\mathrm{n}=39)$ for five days (37). In the other report, data from three trials were combined and overall results described (38). Two of the trials compared FCV $125 \mathrm{mg}, 250 \mathrm{mg}$ or $500 \mathrm{mg}$ thrice daily with ACV $200 \mathrm{mg}$ five times per day for 10 days. A total of 951 patients with first-episode $\mathrm{GH}$ of less than $72 \mathrm{~h}$ duration (40\% primary, $60 \%$ nonprimary) were enrolled. No differences in symptoms, signs or antiviral effects among treatments or between identical doses of FCV administered for five versus 10 days or in the subgroup with primary infection were demonstrated. Tolerance was good, with no differences among doses or treatments. The large sample sizes reduced the likelihood that a difference in efficacy between FCV and ACV was missed, ie, a type II error. In Europe, FCV $250 \mathrm{mg}$ thrice daily for five days has been approved for the treatment of first episodes of $\mathrm{GH}$ in immunocompetent patients.

VCV $1000 \mathrm{mg}$ twice daily was not different in efficacy and safety compared with ACV $200 \mathrm{mg}$ five times per day for 10 days in patients with lesion durations of less than $72 \mathrm{~h}$ (39). There were similar proportions of primary and nonprimary infections in both treatment groups. The intent-to-treat analysis revealed identical median times to healing in both groups (nine days). These results combined with data showing that VCV 500 mg twice daily yields a daily area-under-the-plasma concentration versus time curve approximately twofold greater than is achieved with ACV $200 \mathrm{mg}$ five times per day has in part resulted in approval of VCV $500 \mathrm{mg}$ twice daily for 10 days for the treatment of first-episode GH in many European countries. In the United States, the approved dose regimen is 
$1000 \mathrm{mg}$ twice daily for 10 days. The available data suggest that oral ACV $200 \mathrm{mg}$ five times per day for 10 days, FCV 250 $\mathrm{mg}$ thrice daily for five days and VCV $500 \mathrm{mg}$ to $1000 \mathrm{mg}$ twice daily for 10 days are comparable for the treatment of firstepisode GH in otherwise healthy patients with disease of less than $72 \mathrm{~h}(\mathrm{VCV})$ or up to five days (FCV). Whether oral ACV is the only one of the three agents to be efficacious in patients with first-episode disease from five to seven days duration at treatment initiation is uncertain because only oral ACV has been studied in such individuals. It also remains to be demonstrated that twice daily and thrice daily dosing schedules for VCV and FCV, respectively, are more effective in patients due to the more convenient dose schedule than is recommended for oral ACV.

\section{Recurrent genital infection}

Brief courses of therapy for episodes of recurrent $\mathrm{GH}$ in immunocompetent adults with topical ACV and oral ACV, FCV and VCV yield modest clinical benefit, whereas chronic suppressive therapy with oral ACV, FCV and VCV produces more dramatic benefits.

Episode therapy: The treatment of episodes of recurrent $\mathrm{GH}$ with a brief course of topical or oral ACV yielded modest and inconsistent therapeutic effects of two types. First, the severity and duration of lesion symptoms and signs was reduced, albeit inconsistently, and, second, treatment initiated early in the course of a recurrence aborted some episodes. ACV 5\% ointment applied four to six times per day beginning one to two days after the onset of symptoms of recurrent $\mathrm{GH}$ in three trials reduced the duration of HSV excretion compared with placebo ointment, although not always in both women and men (40-42). However, the duration of pain was not altered while time to healing was accelerated only in males in one of three studies. When an attempt was made to improve therapy by initiating it within $6 \mathrm{~h}$ of the onset of the prodrome of a recurrence and before actual lesion formation had occurred, only limited additional beneficial effects of borderline significance were observed: a reduced interval between lesion formation and crusting in men using ACV was observed in addition to a diminished duration of viral excretion in ACV female recipients only (43). Topical ACV 5\% cream initiated by patients during the prodromal stage was more effective than placebo (44). ACV reduced the duration of pain from a median of 4.5 days in placebo recipients to three days in AVCtreated subjects, shortened healing time by $16 \%$ from six to five days and reduced new lesion formation by $77 \%$ during five days of therapy compared with the placebo cream (44). Neither ACV 5\% cream nor ointment is approved for therapy of recurrent GH in Canada. The efficacy of PCV cream, which is approved for the treatment of recurrent herpes labialis, for therapy of recurrent $\mathrm{GH}$, has not been reported.

Early studies with oral ACV $200 \mathrm{mg}$ five times per day for five days demonstrated therapeutic effects that somewhat exceeded those observed with topical 5\% ACV ointment or cream, but remained modest in extent and degree (45-47). In the early studies, oral ACV significantly reduced mean healing time by $16 \%$ to $25 \%$ and also the duration of HSV excretion compared with placebo. The duration of lesion pain was not reduced $(0.05<\mathrm{P}<0.10)$, but the small sample size likely precluded demonstration of a significant effect of ACV (46). In a large study of 688 adult volunteers (48), oral ACV $200 \mathrm{mg}$ five times per day initiated at less than or equal to $24 \mathrm{~h}$ after the appearance of symptoms or signs of a recurrence of $\mathrm{GH}$ herpes compared with placebo reduced the median duration of lesion pain by $19 \%$, from 5.9 days to 4.8 days, as well as the severity of pain. Attempts to enhance the therapeutic effect by the earlier initiation of therapy and the use of a larger dose have not been effective: the efficacy of therapy initiated by the patient at the earliest symptom of a recurrence or by the physician as soon as possible in the clinic was formally tested in a doubleblind, placebo controlled, crossover trial (49). No significant difference was observed between ACV treatment with $200 \mathrm{mg}$ five times per day initiated at a mean interval of $10 \mathrm{~h}$ (patientinitiated therapy) compared with $25 \mathrm{~h}$ (clinic-initiated therapy) after the appearance of the first symptom of a recurrence, although ACV efficacy exceeded placebo in both arms. Treatment with $800 \mathrm{mg}$ of ACV twice daily for five days was not more efficacious than the currently recommended dose of $200 \mathrm{mg}$ five times per day for five days (50).

Oral ACV therapy initiated in the prodromal phase of a recurrence may prevent progression to the formation of a lesion. However, this effect has also not been consistently observed: therapy with ACV $200 \mathrm{mg}$ five times per day or $800 \mathrm{mg}$ twice daily or placebo, all for five days, prevented lesion formation in $12 \%, 11 \%$ and $3 \%$ of treatment courses, respectively (50). A similar trend was observed in the formal crossover study of patient- and clinic-initiated therapy of Ruhnek-Forsbeck et al (49). Patient-initiated therapy increased the incidence of aborted attacks by $51 \%(\mathrm{P}=0.067)$, from $19 \%$ in placebo recipients to $39 \%$ in ACV recipients, whereas clinic-initiated therapy increased the incidence by $46 \%(\mathrm{P}=0.17)$, from $14 \%$ to $26 \%$. Insufficient sample sizes precluded the demonstration that these differences were statistically significant. Collectively, these data suggest that for oral ACV therapy of recurrent $\mathrm{GH}$, patient-initiated treatment will be required. This will in turn require education and instruction that permits the earliest possible initiation of therapy after the appearance of symptoms of recurrent disease.

VCV $500 \mathrm{mg}$ twice daily and FCV $125 \mathrm{mg}$ twice daily, both for five days, have recently been approved for the treatment of episodes of recurrent GH. VCV $500 \mathrm{mg}$ twice daily initiated at a median of less than $12 \mathrm{~h}$ after lesion or symptom onset reduced the median duration of lesion symptoms and signs by $32 \%$ (from 5.9 days to 6.0 days to 4.0 days to 4.1 days) compared with placebo (51). Doubling the dose did not yield better results. Median lesion HSV excretion was reduced $50 \%$ by both VCV doses, from four days to two days, and both doses increased the proportion of patients with aborted episodes by 33\% (VCV $500 \mathrm{mg}$ twice daily) and 48\% (VCV $1000 \mathrm{mg}$ twice daily). In another large study, VCV $500 \mathrm{mg}$ twice daily and ACV $200 \mathrm{mg}$ five times per day, both for five days, were equally effective in a patient-initiated study (52). It is difficult to reconcile data demonstrating greater efficacy of VCV than placebo in the study of Spruance et al (51), the lack of substantive difference between ACV and placebo (vide supra) and the comparable effects of VCV and ACV (52).

FCV doses of $125 \mathrm{mg}, 250 \mathrm{mg}$ and $500 \mathrm{mg}$ twice daily for five days were all more efficacious than placebo for the treatment of recurrent $\mathrm{GH}$ with no differences among FCV doses (53). Patients initiated treatment within $6 \mathrm{~h}$ of the onset of symptoms or signs of a recurrence. In a novel methodological approach used for the first time in this study, subjects were evaluated twice daily during therapy rather than just once, as was 
the usual practice. This permitted more accurate determination of therapeutic endpoints. The duration of lesion symptoms, healing times and HSV shedding from lesions were significantly reduced by all doses of FCV compared with placebo. The study design precluded the evaluation of an effect of FCV therapy on the frequency of aborted lesions. FCV $125 \mathrm{mg}$ twice daily for five days is approved for therapy of recurrent $\mathrm{GH}$.

In two recently reported studies, the benefits of a shorter, two- to three-day course of oral antiviral therapy for the treatment of recurrent $\mathrm{GH}$ have been reported. In the first study, three days of treatment of recurrent genital HSV infection with VCV $500 \mathrm{mg}$ twice daily, self-initiated within $24 \mathrm{~h}$ of a first symptom or sign of recurrent disease, was as effective and well tolerated as five-day treatment (54). The percentages of patients with aborted lesions were $25 \%$ and $26 \%$ in the two groups. Large sample sizes were tested: 402 volunteers received three days of VCV plus two days placebo and 398 volunteers received five days of VCV. This element of the study design obviated a Type II error with a power of $80 \%$ to detect a difference of $20 \%$ or more between treatments. In the second study, Wald et al (55) evaluated the efficacy and tolerance of ACV $800 \mathrm{mg}$ thrice daily compared with placebo for two days of treatment of a recurrent episode of GH. Volunteers selfinitiated therapy within $12 \mathrm{~h}$ of onset. ACV was more effective than placebo in reducing the duration of all symptoms and lesion duration (both from a median of six days to four days), viral shedding by $57 \%$ (from $58.5 \mathrm{~h}$ to $25 \mathrm{~h}$ ) and increasing the proportion of aborted episodes from $11 \%$ to $27 \%$ (all $\mathrm{P}<0.05$ ). These effects of two days of oral antiherpes drug therapy are similar to those observed with five days of therapy with ACV, FCV and VCV (vide supra). Tolerance was not specifically reported. These studies strongly suggest that a shorter course of treatment than is conventionally recommended for the treatment of recurrent genital HSV infection may be sufficient.

All treatments with topical and oral ACV and VCV and FCV have been well tolerated with no significant differences from placebo. Large study sample sizes, especially with VCV (259 to 368 subjects per group), tended to reduce the likelihood of a Type II error among recorded adverse reactions to therapy.

\section{Suppressive therapy}

Nonpregnant adults: The most dramatic clinical benefits of the pharmacological therapy of recurrent $\mathrm{GH}$ in the immunocompetent host have been observed during long term suppressive therapy. Initially observed during oral ACV therapy, these observations have now been demonstrated with FCV and VCV as well. Suppressive oral ACV is indicated for individuals with frequently recurring disease, which is usually defined as $\mathrm{GH}$ recurring six to eight times or more per year.

Multiple placebo controlled, double-blind trials in which the results of evaluation of a range of ACV doses (56-69) were reported, plus careful longitudinal follow-up of large numbers of subjects for up to five years (70) have provided clinicians with a substantive database that can be used to treat with confidence and to individualize treatment regimens. The dramatic effects will be greater in those with the most frequent recurrences, such as the volunteers in the study of Douglas et al (56), who experienced an average of 13 recurrences in the 12 months before study entry. However, the therapeutic effect is also demonstrable in those with as few as four recurrences per year (61). ACV doses of $200 \mathrm{mg}$ twice daily (56), thrice daily $(57,59)$, four times daily $(60-64)$, five times per day (56) and
$400 \mathrm{mg}$ twice daily $(65-67,69)$ and $800 \mathrm{mg}$ once daily (68) were all more effective than placebo in double-blind trials, although none was completely effective in preventing breakthroughs. Both total daily dose and the frequency of tablet taking appear to be determinants of the efficacy of suppression. In the only controlled trial in which placebo and different doses of ACV were compared, ACV $200 \mathrm{mg}$ twice daily was as effective in preventing recurrences as $200 \mathrm{mg}$ five times per day over a 12-week period (56). The efficacy of ACV administered once a day appears to be less than with schedules utilizing the same total daily dose administered in two or more divided doses. This conclusion was suggested by the trial of Mindel et al (71) in which prophylactic efficacy declined as the ACV dose was reduced from $200 \mathrm{mg}$ four times daily to thrice daily to twice daily to once daily, each for 12 weeks. As well, ACV 800 $\mathrm{mg}$ in four or two divided doses appeared to be more effective than a once daily dose. All once daily doses (200, 400 or 800 $\mathrm{mg}$ ) were significantly less effective than ACV 200 four times daily. Only $25 \%$ of individuals receiving ACV $200 \mathrm{mg}$ once daily were recurrence-free after 12 weeks. Although no placebo-treated control group was studied concurrently, this $25 \%$ level of suppressive efficacy was very low and may approach the lower limit of efficacy. In the only controlled trial utilizing $800 \mathrm{mg}$ once daily, only $28 \%$ of recipients were recurrence-free during two years of therapy compared with no placebo recipients (68). In individuals with a reported annual recurrence rate of 12 or more episodes, daily ACV $200 \mathrm{mg}$ thrice daily was more effective than ACV $400 \mathrm{mg}$ thrice daily ingested on Saturday and Sunday only during a 70-day study (58).

In Canada, ACV doses of $200 \mathrm{mg}$ thrice daily to five times per day or $400 \mathrm{mg}$ twice daily are all approved for the suppression of frequently recurring $\mathrm{GH}$ in healthy adults. The data suggest that the dose-response curve of ACV from 400 to $1000 \mathrm{mg} /$ day in divided doses is relatively flat and that increasing the dose over this range is unlikely to enhance the suppressive effect. Whether ACV doses substantially greater than $1000 \mathrm{mg} /$ day, such as $4000 \mathrm{mg} /$ day, used to treat patients with herpes zoster will be more efficacious for the suppression of recurrent $\mathrm{GH}$ is unknown.

The safety of ACV for the suppression of frequently recurring $\mathrm{GH}$ in immunocompetent adults has been repeatedly demonstrated in multiple placebo controlled trials of nine weeks (57), 12 weeks $(60-64,67), 17$ to 18 weeks $(56,57), 26$ weeks $(59)$ and one year $(65,66,68,69)$. This favourable safety profile compared with concurrent placebo treatment has been paralleled by a report of ACV safety during open-label use for one year (71) and up to five years (70). In these immunocompetent adults, resistance has not been demonstrated by in vitro testing of HSV isolates obtained before, during or after ACV suppressive therapy $(56,60,65-67,72)$.

Not surprisingly, FCV $(73,74)$ and VCV $(69,75)$ are also efficacious and safe for the suppression of frequently recurring GH. Two studies have demonstrated the efficacy and safety of FCV for the suppression of frequently recurring GH. Three hundred seventy-five women with six or more episodes of GH in the previous 12 months were randomly assigned to four months of treatment with one of six different treatments: placebo, FCV $125 \mathrm{mg}$ or $250 \mathrm{mg}$ once or twice daily, or $500 \mathrm{mg}$ once daily (73). The most effective regimen for suppressing recurrent genital lesions was $250 \mathrm{mg}$ twice daily. Once daily doses of $125 \mathrm{mg}$ or $500 \mathrm{mg}$ were ineffective compared with placebo, while $125 \mathrm{mg}$ twice daily and $250 \mathrm{mg}$ once daily were interme- 
diate in efficacy. All doses were well tolerated compared with placebo. No resistance to PCV was demonstrable in HSV isolates recovered during or after FCV suppressive therapy. In another study, 223 healthy men and 232 healthy women with six or more episodes of $\mathrm{GH}$ per year were randomly allocated to FCV $125 \mathrm{mg}$ or $250 \mathrm{mg}$ thrice daily, $250 \mathrm{mg}$ twice daily or placebo for 52 weeks (74). At one year, $71 \%$ to $80 \%$ of volunteers receiving FCV were recurrence-free compared with $22 \%$ of placebo recipients. There was no difference in efficacy between men and women and all doses were as well tolerated as placebo. Based on the greater convenience of FCV $250 \mathrm{mg}$ twice daily, this regimen has been selected for marketing and is approved by the TPD for the suppression of frequently recurring $\mathrm{GH}$.

VCV suppressive efficacy and safety have been evaluated in two large trials $(69,75)$. Reitano et al $(69)$ undertook a formal dose-response evaluation of the suppressive efficacy of VCV administered once daily for a period of one year. In a randomized trial of 1479 adults (709 men), VCV once daily doses of $250 \mathrm{mg}, 500 \mathrm{mg}$ and $1000 \mathrm{mg}, 250 \mathrm{mg}$ twice daily, ACV $400 \mathrm{mg}$ twice daily and placebo were compared. After one year, the percentages of patients who were recurrence-free were $22 \%, 40 \%, 48 \%, 50 \%, 49 \%$ and 5\%, respectively. All active treatments were more effective than placebo and were as well tolerated. The once daily dose-response evaluation demonstrated that VCV $500 \mathrm{mg}$ and $1000 \mathrm{mg}$ were more effective than $250 \mathrm{mg}$. There was no statistically significant difference between VCV $250 \mathrm{mg}$ twice daily or $1000 \mathrm{mg}$ once daily or ACV $400 \mathrm{mg}$ twice daily; VCV $250 \mathrm{mg}$ twice daily tended to be more effective than $500 \mathrm{mg}$ once daily. In those with 10 or more recurrences of GH per year, VCV $1000 \mathrm{mg}$ appeared to be more effective than $500 \mathrm{mg}$ once daily and was similar to VCV $250 \mathrm{mg}$ twice daily and ACV $400 \mathrm{mg}$ twice daily. In another randomized study of 382 volunteers, VCV $500 \mathrm{mg}$ once daily for four months was efficacious and safe compared with placebo (75). Approximately equal proportions of male and female volunteers with a history of eight or more recurrences per year were studied. After four months, $69 \%$ of VCV recipients were still recurrence-free compared with $9.5 \%$ of placebo recipients. VCV is licensed in Canada for suppressive therapy: $500 \mathrm{mg}$ once daily is recommended for those with nine or fewer recurrences per year and $1000 \mathrm{mg}$ once daily for those with more recurrences.

The durability of the suppressive effects of ACV has been demonstrated in 1146 subjects with 12 or more recurrences per year who received placebo or ACV $400 \mathrm{mg}$ twice daily for the first year with ACV $200 \mathrm{mg}$ five times per day for five days to treat recurrences, followed by the treatment of all subjects thereafter with ACV $200 \mathrm{mg}$ twice daily for four more years (70). Fifty-three per cent to $70 \%$ of patients were recurrencefree in any given year and 20\% were recurrence-free for the entire five years; $3.3 \%$ of subjects required an increased dose of $800 \mathrm{mg}$ twice daily for 12 or more recurrences per year. The durability of the suppressive effects of FCV beyond four months remains to be demonstrated; VCV is effective for at least one year (69).

The relative costs of ACV, FCV and VCV in Manitoba for the treatment of $\mathrm{GH}$ outbreaks using drugs and regimens approved by the TPD are shown in Table 2 .

Pregnant women: ACV suppressive therapy given to pregnant women with GH prevented recurrent $\mathrm{GH}$ disease and obviated caesarean section for the prevention of neonatal herpes in two reports $(76,77)$. In one study, 46 women with a history of recurrent GH received ACV $200 \mathrm{mg}$ four times daily beginning one week before the expected date of confinement, while 46 controls received no treatment (76). In a placebo controlled, double-blind clinical trial, 46 women who had a first clinical episode of $\mathrm{GH}$ in pregnancy were randomly allocated to receive $400 \mathrm{mg} \mathrm{ACV}$ thrice daily (21 women) or placebo $(n=25)$ beginning at 36 weeks of gestation (77). ACV recipients did not develop recurrent disease in either study and, therefore, did not require caesarean section to prevent neonatal herpes, whereas 12 of 46 and nine of 25 recipients in the control group in the two trials, respectively, had recurrent disease at delivery; nine of 12 and nine of 25 in the two studies with recurrent disease, respectively, had caeserean sections to

\section{TABLE 2}

Therapeutic Products Directorate (TPD) of Health Canada approved indications for the treatment of mucocutaneous herpes simplex virus infections in the normal host

\begin{tabular}{|c|c|c|c|}
\hline Indication & Drugs and formulation & Dose regimen & Treatment cost \\
\hline Cold sores & Penciclovir $1 \%$ cream & Apply 6 times in day 1 , then every $2 \mathrm{~h}$ while awake for 3 days & Not available \\
\hline \multicolumn{4}{|l|}{ Genital herpes } \\
\hline \multirow[t]{3}{*}{ First-episode } & Acyclovir $200 \mathrm{mg}$ tablets & $200 \mathrm{mg} 5$ times per day for 10 days & $\$ 49.00$ \\
\hline & Acyclovir $5 \%$ cream or ointment & Apply 4 to 6 times per day for a maximum of 10 days & $\$ 45.00$ per $15 \mathrm{~g}$ tube \\
\hline & Acyclovir injectable & Intravenous $5 \mathrm{mg} / \mathrm{kg}$ over $60 \mathrm{~min}$ every $8 \mathrm{~h}$ for 7 days & $\$ 4.35$ per $500 \mathrm{mg}$ vial \\
\hline \multicolumn{4}{|l|}{ Recurrent } \\
\hline \multirow[t]{3}{*}{ Episode therapy } & Acyclovir $200 \mathrm{mg}$ tablets & $200 \mathrm{mg} 5$ times per day for 5 days & $\$ 25.00$ \\
\hline & Famciclovir $125 \mathrm{mg}$ tablets & $125 \mathrm{mg}$ twice during waking hours for 5 days & $\$ 28.00$ \\
\hline & Valacyclovir $500 \mathrm{mg}$ tablets & $500 \mathrm{mg}$ twice during waking hours for 5 days & $\$ 33.00$ \\
\hline \multirow[t]{3}{*}{ Suppressive therapy } & Acyclovir $200 \mathrm{mg}$ tablets & $\begin{array}{l}200 \mathrm{mg} \text { thrice during waking hours to } 5 \text { times per day or } \\
400 \mathrm{mg} \text { twice during waking hours for for } 1 \text { month }\end{array}$ & $\$ 90.00, \$ 150.00$ or $\$ 120.00$ \\
\hline & Famciclovir $250 \mathrm{mg}$ tablets & $250 \mathrm{mg}$ twice during waking hours for 1 month & $\$ 228.00$ \\
\hline & Valacyclovir $500 \mathrm{mg}$ tablets & $500 \mathrm{mg}$ or $1000 \mathrm{mg}$ once daily for 1 month & $\$ 102.00$ or $\$ 204.00$ \\
\hline
\end{tabular}


TABLE 3

Thirteen off-label indications for drug therapy of mucocutaneous herpes simplex virus infections in the normal host

\begin{tabular}{|c|c|c|c|}
\hline Indication & Drugs and formulation & Dose regimen & Treatment cost \\
\hline \multicolumn{4}{|l|}{ Orolabial herpes } \\
\hline \multicolumn{4}{|l|}{ Gingivostomatitis } \\
\hline Therapy & Acyclovir suspension & $\begin{array}{l}15 \mathrm{mg} / \mathrm{kg} 5 \text { times per day for } 7 \text { days or } 600 \mathrm{mg} / \mathrm{m}^{2} \\
4 \text { times during waking hours for } 10 \text { days }\end{array}$ & $\begin{array}{l}\$ 29.00 \text { for } 125 \mathrm{~mL} \\
\text { of } 40 \mathrm{mg} / \mathrm{mL}\end{array}$ \\
\hline Prophylaxis & Acyclovir $200 \mathrm{mg}$ tablets & 30 to $60 \mathrm{mg} / \mathrm{kg}$ in 3 to 5 doses per day for 7 days & $\$ 1.00$ per tablet \\
\hline \multicolumn{4}{|l|}{ Recurrent cold sores } \\
\hline Episode therapy & Acyclovir $200 \mathrm{mg}$ tablets & $400 \mathrm{mg} 5$ times per day for 5 days & $\$ 48.50$ \\
\hline Suppressive therapy & Acyclovir $200 \mathrm{mg}$ tablets & $\begin{array}{l}400 \mathrm{mg} \text { twice during waking hours or } \\
200 \mathrm{mg} 4 \text { times during waking hours }\end{array}$ & $\begin{array}{l}\$ 4.00 \text { per day } \\
\$ 4.00 \text { per day }\end{array}$ \\
\hline $\begin{array}{l}\text { Prophylaxis after trigeminal } \\
\text { nerve surgery }\end{array}$ & Acyclovir $200 \mathrm{mg}$ tablets & $\begin{array}{l}400 \mathrm{mg} \text { twice during waking hours started at bedtime } \\
\text { before surgery and for } 5 \text { days }\end{array}$ & $\$ 19.40$ \\
\hline \multirow[t]{4}{*}{ During sun exposure } & Acyclovir $200 \mathrm{mg}$ tablets & 400 mg twice during waking hours for 7 days before sun exposure & $\$ 27.00$ \\
\hline & Acyclovir $5 \%$ cream & $\begin{array}{l}\text { Apply } 2 \text { hours before sun exposure and then } 6 \text { times per day } \\
\text { for } 7 \text { days skiing }\end{array}$ & $\$ 45.00$ per $15 \mathrm{~g}$ tube \\
\hline & & Apply 4 times during waking hours to sites of recurrent disease & \\
\hline & Valacyclovir $500 \mathrm{mg}$ tablets & 500 mg once daily & $\$ 3.40$ per day \\
\hline $\begin{array}{l}\text { Recurrent erythema } \\
\text { multiforme prevention }\end{array}$ & Acyclovir $200 \mathrm{mg}$ tablets & $\begin{array}{l}400 \mathrm{mg} \text { twice during waking hours or } 200 \mathrm{mg} 4 \text { times during } \\
\text { waking hours }\end{array}$ & $\$ 4.00$ per day both \\
\hline Eczema herpeticum - therapy & Acyclovir $200 \mathrm{mg}$ tablets & $200 \mathrm{mg} 5$ times per day for 5 days & $\$ 25.00$ \\
\hline \multicolumn{4}{|l|}{ Genital herpes - therapy } \\
\hline \multirow[t]{3}{*}{ First-episode } & Valacyclovir $500 \mathrm{mg}$ tablets & $500 \mathrm{mg}$ twice during waking hours for 10 days or & $\$ 68.00$ \\
\hline & & 1000 mg twice during waking hours for 10 days & $\$ 135.20$ \\
\hline & Famciclovir $250 \mathrm{mg}$ tablets & $250 \mathrm{mg}$ thrice during waking hours for 5 days & $\$ 57.00$ \\
\hline \multicolumn{4}{|l|}{ Recurrent } \\
\hline \multirow{2}{*}{$\begin{array}{l}\text { Short course therapy of } \\
2 \text { to } 3 \text { days }\end{array}$} & Valacyclovir $500 \mathrm{mg}$ tablets & $500 \mathrm{mg}$ twice during waking hours for 3 days & $\$ 20.40$ \\
\hline & Acyclovir $200 \mathrm{mg}$ tablets & $800 \mathrm{mg} 3$ times during waking hours for 2 days & $\$ 23.30$ \\
\hline \multirow[t]{2}{*}{$\begin{array}{l}\text { Suppressive therapy in } \\
\text { pregnant women }\end{array}$} & Acyclovir $200 \mathrm{mg}$ tablets & $\begin{array}{l}200 \text { mg } 4 \text { times during waking hours beginning } 1 \text { week } \\
\text { before expected date of confinement }\end{array}$ & $\$ 27.20$ per week \\
\hline & & $\begin{array}{l}400 \text { mg thrice during waking hours beginning at } 36 \text { weeks' } \\
\text { gestation }\end{array}$ & $\$ 163.00$ for 4 weeks \\
\hline $\begin{array}{l}\text { Asymptomatic shedding in } \\
\text { nonpregant women }\end{array}$ & Acyclovir $200 \mathrm{mg}$ tablets & $400 \mathrm{mg}$ twice during waking hours & $\$ 4.00$ per day \\
\hline Herpes proctitis & Acyclovir $200 \mathrm{mg}$ tablets & $400 \mathrm{mg} 5$ times per day for 5 days & $\$ 97.00$ \\
\hline
\end{tabular}

prevent neonatal herpes. Asymptomatic shedding from the exocervix or vulva at parturition was only observed in one of the 71 control women. ACV was well tolerated by the mothers and seemingly so by the neonates. No neonate developed herpes, but neither study was powered to demonstrate a protective effect of ACV. These data are consistent with the suppressive effect of ACV in nonpregnant women, but this use of ACV remains an off-label one whose efficacy and safety remain to be rigorously tested before it is recommended as a standard in contemporary obstetrical practice.

\section{Asymptomatic HSV shedding in women}

The favorable effect of suppressive ACV on lesion recurrence has been paralleled by a reduction in subclinical shedding in women (78). In a double-blind, placebo controlled crossover trial of 34 women with recurrent GH, ACV 400 mg twice dai- ly for 70 days reduced the number of days when HSV was detected in exocervix, vulvar or perineal swabs, in the absence of genital lesions, by $94 \%$ from a mean of 6.9 days to 0.3 days. Shedding was reduced similarly in all sites but was completely prevented by ACV in 78\% (20 of 26) of women who completed both arms of the study and by placebo in 23\% (six of 26), demonstrating that this pharmacological effect is not absolute. It is likely, but has not been demonstrated, that a similar effect would be observed on asymptomatic genital HSV shedding in men. Whether ACV-induced suppression of asymptomatic HSV genital shedding can reduce the risk of transmission is not known.

In addition to preventing recurrent genital HSV lesions, suppressive ACV has been demonstrated to ameliorate the psychological morbidity of the disease (79). In 102 unselected patients (mean age 31 years; 54\% male; 62\% single), psycho- 
logical tests demonstrated pathological levels of "illness concern" and anxiety in approximately $60 \%$ of subjects. ACV therapy for a year was associated with a $42 \%$ to $60 \%$ reduction in the number of subjects with these types of morbidity by three months, a therapeutic effect that was sustained thereafter. It is likely that FCV and VCV will produce similar beneficial effects on the mental health of patients with $\mathrm{GH}$, although this has not yet been demonstrated.

Thus, at this time, approved doses for the suppression of frequently recurring GH include ACV $200 \mathrm{mg}$ twice daily to five times per day or $400 \mathrm{mg}$ twice daily, FCV $250 \mathrm{mg}$ twice daily and VCV $500 \mathrm{mg}$ or $1000 \mathrm{mg}$ once daily. Whether once daily VCV therapy will result in better compliance than multiple dose schedules has not yet been studied, but the convenience of taking a minimum of daily doses has an intuitive appeal for the prescribing doctor recommending a long term suppressive pharmacological regimen. Notwithstanding the substansial effects of suppressive therapy, two caveats must be kept in mind. First, neither the effects of drug therapy on lesion recurrence, nor their effects on shedding of virus during lesions-free periods, is absolute. Second, it cannot be assumed that transmission will be prevented, although the risk of this would intuitively be expected to be reduced during chronic therapy.

The duration of suppressive therapy to prevent recurrent genital lesions can be tailored to the need of the individual patient, having regard for the limited data on duration for suppression with FCV. ACV ingested continuously for up to five years, FCV for 16 weeks and VCV for 52 weeks have been demonstrated to be efficacious and safe. However, if one wishes to minimize drug exposure and its attendant cost, one can interrupt treatment periodically and expect that a few individuals will have experienced regression of their $\mathrm{GH}$ to a latent state. During 12 weeks of placebo therapy in ACV trials, a median of $7 \%$ (range $0 \%$ to $10 \%$ ) $(60-64,67)$ were recurrencefree; during 17 to 26 weeks, a median of $0 \%$ (range $0 \%$ to $6 \%$ ) $(56,57,59)$ were recurrence-free and during one year of suppressive placebo therapy, a median of $4 \%$ (range $0 \%$ to $5 \%$ ) $(65,66,68,69)$ were recurrence-free. Spontaneous remission was also observed during trials of placebo controlled FCV and VCV suppressive therapy. In individuals with six or more recurrences in twelve months treated with placebo, 10\% (75) and $42 \%(73)$ were recurrence-free at four months, $27 \%(74)$ were recurrence-free at six months and 5\% (69) to 22\% (74) were recurrence-free after one year of placebo therapy. Factors contributing to this relatively high prevalence of recurrencefree placebo recipients in FCV and VCV trials compared with ACV suppressive therapy trials may have included a high (55\%) withdrawal rate due to lack of efficacy (74) or enrolment of subjects with a lower median frequency rate in the year before the study, 7 (73), compared with median yearly frequency rates of 11 (63) to 13 (65) in almost all studies of ACV for the suppression of frequently recurring $\mathrm{GH}(56-69,71)$. In conclusion, one strategy to minimize the use of ACV, FCV and $\mathrm{VCV}$ for suppressive therapy is to stop treatment every 12 to 24 weeks and only to reinstate it if the next two consecutive recurrences occur in a one- to two-month period, consistent with greater than or equal to six recurrences per year.

\section{HERPES PROCTITIS}

Oral ACV was more effective than placebo for the treatment of a first episode of culture-proved HSV proctitis in 29 HIV-negative homosexual men (80). Of 15 men treated with
$\mathrm{ACV}$, seven had primary infection as did 10 of 14 treated with placebo. ACV $400 \mathrm{mg}$ five times per day initiated within 12 days of the onset of symptoms and continued for 10 days reduced the median healing time from 14 to five days in the placebo recipients $(\mathrm{P}<0.01)$ and the median duration of virus shedding from 11 to zero days $(\mathrm{P}<0.05)$, respectively. Durations of local symptoms and signs of proctitis were reduced in ACV recipients, but the small sample sizes precluded the demonstration of a statistically significant effect of ACV therapy on these parameters. ACV $2 \mathrm{~g}$ per day was as well tolerated as placebo. Treatment of first-episode herpes proctitis up to 12 days after the onset of symptoms in HIV-negative men would appear to be an appropriate off-label use for ACV.

\section{CONCLUSIONS}

ACV has been the prototype agent and mainstay of contemporary pharmacological therapy of orolabial and anogenital HSV infection in the immunocompetent host as demonstrated by data supporting TPD-approved indications and off-label uses. For most off-label indications, the evidence base is limited to studies conducted using ACV as the antiherpes drug (Table 3). The absence of comparative trials precludes definitive conclusions about the relative advantages of ACV, FCV, PCV and VCV for these infections. However, VCV and FCV for the treatment of first-episode $\mathrm{GH}$ will be more convenient than five times per day oral ACV. Topical PCV and oral FCV and VCV for therapy of episodes of recurrent orolabial and genital infection, respectively, may be more efficacious and convenient than ACV formulations for these infections. Recently reported studies strongly suggest that alternative regimens of VCV for three days and ACV at an increased dose for two days yield therapeutic effects comparable with traditional five-day treatments for episode therapy. Once daily VCV is more convenient than multiple dose regimens for suppression of frequently recurring $\mathrm{GH}$, but a larger total daily dose appears to be necessary. For the suppression of HSV infection in pregnant women, ACV is the antiherpes agent of choice, based on substantial cumulative evidence. Drug resistance has not been a limiting factor in the treatment of HSV infections in the immunocompetent host.

Until robust comparative trials identify the best agent and optimal dose regimen, infectious disease clinicians will need to judiciously select among the available agents, formulations and dose regimens based on clinical trials data, as well as cost, to provide the most appropriate therapy for their patients.

\section{REFERENCES}

1. de Miranda P, Blum MR. Pharmacokinetics of acyclovir after intravenous and oral administration. J Antimicrob Chemother 1983;12(Suppl B):29-37.

2. Soul-Lawton J, Seaber E, On N, et al. Absolute bioavailability and metabolic disposition of valaciclovir, the L-valyl ester of acyclovir, following oral administration to humans. Antimicrob Agents Chemother 1995;39:2759-64.

3. Pue MA, Benet LZ. Pharmacokinetics of famciclovir in man. Antiviral Chem Chemother 1993;4(Suppl 1):47-55.

4. Lewis LD, Fowle ASE, Bittiner SB, et al. Human gastrointestinal absorption of acyclovir from tablet, duodenal infusion and sipped solution. Br J Clin Pharmacol 1986;21:459-62.

5. de Miranda P, Burnette TC, Smith C, et al. Mechanisms of the enhanced oral bioavailability of acyclovir with the prodrug valacyclovir $\mathrm{HCl}\left(\right.$ Valtrex $\left.^{\mathrm{TM}}\right)$. 34th Interscience Conference on Antimicrobial Agents and Chemotherapy. Orlando, October 4 to 7, 1994. (Abst A70) 
6. Weller S, Blum MR, Doucette M, et al. Pharmacokinetics of the acyclovir pro-drug valaciclovir after escalating single and multipledose administration to normal volunteers. Clin Pharmacol Ther 1993;54:595-605.

7. Filer CW, Allen GD, Brown TA, et al. Metabolic and pharmacokinetic studies following oral administration of $14 \mathrm{C}$ famciclovir to healthy subjects. Xenobiotica 1994;24:357-68.

8. Elion GB. Mechanism of action and selectivity of acyclovir. Acyclovir Symposium. Am J Med 1982;73:7-13.

9. Vere Hodge RA, Cheng Y-C. The mode of action of penciclovir. Antiviral Chem Chemother 1993;4(Suppl 1):13-24.

10. Darby G, Field HJ, Salisbury SA. Altered substrate specificity of herpes simplex virus thymidine kinase confers acyclovir resistance. Nature 1981;289:81-3.

11. Ehrlich KS, Mills J, Chatis P, et al. Acyclovir-resistant herpes simplex virus infection in patients with the acquired immunodeficiency syndrome. N Engl J Med 1989;320:293-6.

12. Englund JA, Zimmerman ME, Swierkosz EM, et al. Herpes simplex virus resistant to acyclovir. Ann Intern Med 1990;112:416-22.

13. Amir J, Harel L, Smetana Z, et al. Treatment of herpes simplex gingivostomatitis with acyclovir in children: a randomized double blind placebo controlled study. BMJ 1997;314:1801-3.

14. Aoki FY, Law BJ, Hammond GW, et al. Acyclovir (ACV) suspension for treatment of acute herpes simplex virus (HSV) gingivostomatitis in children: a placebo (PL)-controlled, doubleblind trial. 33rd Interscience Conference on Antimicrobial Agents and Chemotherapy. New Orleans, October 15 to 17, 1993. (Abst 1530)

15. Kuzushima K, Kudo T, Kimura H, et al. Prophylactic oral acyclovir in outbreaks of primary herpes simplex virus Type 1 infection in a closed community. Pediatr 1992;89:379-83.

16. Sullender WM, Arvin AM, Diaz PS, et al. Pharmacokinetics of acyclovir suspension in infants and children. Antimicrob Agents Chemother 1987;31:1722-6.

17. Fiddian AP, Ivanyi L. Topical acyclovir in the management of recurrent herpes labialis. Br J Dermatol 1983;109:321-6.

18. Spruance SL, Schnipper LE, Overall JC Jr, et al. Treatment of herpes simplex labialis with topical acyclovir in polyethylene glycol. J Infect Dis 1982;146:85-90.

19. Fiddian AP, Yeo JM, Stubbins R, et al. Successful treatment of herpes labialis with topical acyclovir. BMJ 1983;286:1699-701.

20. Spruance SL, Stewart JCB, Rome NH, et al. Treatment of recurrent herpes labialis with oral acyclovir. J Infect Dis 1990;161:185-90.

21. Spruance SL, Rea TL, Thoming C, et al. Penciclovir cream for the treatment of herpes simplex labialis. JAMA 1997;277:1374-9.

22. Rooney JF, Straus SE, Mannix ML, et al. Oral acyclovir to suppress frequently recurrent herpes labialis. Ann Intern Med 1983;118:268-72.

23. Thomas RHM, Dodd HJ, Yeo JM, et al. Oral acyclovir in the suppression of recurrent non-genital herpes simplex virus infection. Br J Dermatol 1985;113:731-5.

24. Baker DA, Deeter RG, Redder K, et al. Valacyclovir effective for suppression of recurrent HSV-1 herpes labialis. 40th Interscience Conference on Antimicrobial Agents and Chemotherapy. Toronto, September 17 to 20, 2000. (Abst 464)

25. Schadelin J, Schilt HV, Rohner M. Preventive therapy of herpes labialis associated with trigeminal surgery. Am J Med 1988;85(Suppl 2A):46-8.

26. Spruance SL, Hamill ML, Hoge WS, et al. Acyclovir prevents reactivation of herpes simplex labialis in skiers. JAMA 1988;260:1597-9.

27. Raborn GW, Krueger GG, Hamill ML, et al. Topical acyclovir versus placebo cream in prevention of sun-induced herpes simplex labialis: a randomized blinded trial. J Clin Invest 1990;86:A75. (Abst 462)

28. Gibson JR, Klaber MR, Harver SG, et al. Prophylaxis against herpes labialis with acyclovir cream - a placebo-controlled study. Dermatologica 1986;172:104-7.

29. Niimura M, Nishikawa T. Treatment of eczema herpeticum with oral acyclovir. Am J Med 1988;85(Suppl 2A):49-52

30. Scholfield JK, Tatnall FM, Leigh IM. Recurrent erythema multiforme: clinical features and treatment in a large series of patients. Br J Dermatol 1993;128:542-5.

31. Tatnall FM, Scholfield J, Proby C, Leigh IM. A double-blind placebo controlled trial of continuous acyclovir in recurrent erythema multiforme. Br J Dermatol 1991;125(Suppl 38):29. (Abst)
32. Corey L, Adams HG, Brown ZA, et al. Genital herpes simplex virus infections: clinical manifestations, course and complications. Ann Intern Med 1983;98:958-72.

33. Corey L, Benedetti J, Critchlow CW, et al. Treatment of primary first-episode genital herpes simplex virus infections with acyclovir: results of topical, intravenous and oral therapy. J Antimicrob Chemother 1983;12(Suppl B):79-88.

34. Mertz GJ, Critchlow CW, Benedetti J, et al. Double-blind placebocontrolled trial of oral acyclovir in first-episode genital herpes simplex virus infection. JAMA 1984;252:1147-51.

35. Wald A, Benedetti J, Davis G, et al. A randomized, double-blind, comparative trial comparing high- and standard-dose oral acyclovir for first-episode genital herpes infections. Antimicrob Agents Chemother 1994:38:174-6.

36. Kinghorn GR, Abeywickreme I, Jeavons M, et al. Efficacy of combined treatment with oral and topical acyclovir in first episode genital herpes. Genitourin Med 1986;67:186-8.

37. Murphy SM, Ruck F, Kitchin VS. Oral famciclovir (FCV) a new antiherpes agent: comparative study with acyclovir in clinic initiated treatment of first episode genital herpes (FGH). EADV/Triaena Congress. Athens, 1991. (Abst)

38. Loveless M, Harris JRW, Sacks SL. Famciclovir in the management of first-episode genital herpes. Infect Dis Clin Prac 1997;6(Suppl 1):S12-S6

39. Fife KH, Barbarash RA, Rudolph T, et al. Valaciclovir versus acyclovir in the treatment of first episode genital herpes infection. Sex Transm Dis 1997;24:481-6.

40. Corey L, Nahmias AJ, Guinan ME, et al. Trial of topical acyclovir in genital herpes simplex virus infection. $\mathrm{N}$ Engl J Med 1982;306:1313-9.

41. Corey L, Benedetti JK, Critchlow CW, et al. Double-blind controlled trial of acyclovir in genital herpes simplex virus infections. Acyclovir Symposium. Am J Med 1982;73:326-34.

42. Reichman RC, Badger GJ, Guinan ME, et al. Topically administered acyclovir in the treatment of recurrent herpes simplex genitalis: a controlled trial. J Infect Dis 1983;147:336-40.

43. Luby JP, Gnann JW Jr, Alexander WJ, et al. A collaborative study of patient-initiated treatment of recurrent genital herpes with topical acyclovir or placebo. J Infect Dis 1989;150:1-6.

44. Fiddian AP, Kinghorn GR, Goldmeier D, et al. Topical acyclovir in the treatment of genital herpes: a comparison with systemic therapy. J Antimicrob Chemother 1983;12(Suppl B):67-77.

45. Nilsen AE, Assen T, Halsos Am, et al. Efficacy of oral acyclovir in the treatment of initial and recurrent genital herpes. Lancet 1982;2:511-3.

46. Salo AP, Lassus A, Hovi T, et al. Double-blind, placebo-controlled, trial of oral acyclovir in recurrent genital herpes. Eur J Sex Trans Dis 1983;1:95-8.

47. Reichman RC, Badger GJ, Mertz GJ, et al. Treatment of recurrent genital herpes simplex infections with oral acyclovir. JAMA 1984;251:2103-7.

48. Tyring SK, Douglas JM Jr, Corey L, et al. A randomized, placebocontrolled comparison of oral valacyclovir and acyclovir in immunocompetent patients with recurrent genital herpes infections. Arch Dermatol 1998;134:185-91.

49. Ruhnek-Forsbeck M, Sandstrom E, Andersson B, et al. Treatment of recurrent genital herpes simplex infection with oral acyclovir. J Antimicrob Chemother 1985;16:621-8.

50. Goldberg LH, Kaufman R, Conant MA, et al. Oral acyclovir for episodic treatment of recurrent genital herpes. J Am Acad Dermatol 1986;15:256-63.

51. Spruance SL, Tyring SK, DeGregorio B, et al. A large-scale, placebo-controlled, dose-ranging trial of peroral valaciclovir for episodic treatment of recurrent genital herpes. Arch Intern Med 1996;156:1729-35.

52. Bodsworth NJ, Crooks RJ, Borelli S, et al. Valaciclovir versus aciclovir in patient-initiated treatment of recurrent genital herpes: a randomized, double-blind trial. Genitourin Med 1997;73:110-6.

53. Sacks SL, Aoki FY, Diaz-Mitoma F, et al. Patient-initiated, twicedaily oral famciclovir for early recurrent genital herpes. JAMA 1996;276:44-9.

54. Leone PA, Trottier S, Miller JM. Valacyclovir for episodic treatment of genital herpes in a shorter 3-day treatment course compared with 5-day treatment. Clin Infect Dis 2002;34:958-62

55. Wald A, Carrell D, Remington M, et al. Two-day regimen of 
acyclovir for treatment of recurrent genital herpes simplex virus Type 2 infection. Clin Infect Dis 2002;34:944-8.

56. Douglas JM, Critchlow C, Benedetti J, et al. A double-blind study of oral acyclovir for suppression of recurrences of genital herpes simplex virus infection. N Engl J Med 1984;310:1551-6.

57. Strauss SE, Takiff HE, Seidlin M, et al. Suppression of frequently recurring genital herpes. N Engl J Med 1984;310:1545-50.

58. Straus SE, Seidlin M, Takiff HE, et al. Double-blind comparison of weekend and daily regimens of acyclovir for suppression of recurrent genital herpes. Antiviral Res 1986;6:151-9.

59. Sacks SL, Fox R, Levendusky P, et al. Chronic suppression for six months compared with intermittent lesional therapy of recurrent genital herpes using oral acyclovir: effects on lesions and nonlesional prodromes. Sex Transm Dis 1988;15:58-62.

60. Thin RN, Jeffries DJ, Taylor PK, et al. Recurrent genital herpes suppressed by oral acyclovir: a multicentre double blind trial. J Antimicrob Chemother 1985;16:219-26.

61. Mindel A, Weller IVD, Faherty A, et al. Prophylactic oral acyclovir in recurrent genital herpes. Lancet 1984;2:56-9.

62. Kinghorn GR, Jeavons M, Rowland M, et al. Acyclovir prophylaxis of recurrent genital herpes: randomised placebo controlled crossover study. Genitourin Med 1985;61:387-90.

63. Halsos AM, Salo AP, Lassus A, et al. Oral acyclovir suppression of recurrent genital herpes: a double-blind, placebo-controlled, crossover study. Acta Dermato-Venereologica 1985;65:59-63.

64. Blom I, Bäck O, Egelrud T, et al. Long-term oral acyclovir treatment prevents recurrent genital herpes. Dermatologica 1986;173:220-3.

65. Mertz GJ, Jones CC, Mills J, et al. Long-term acyclovir suppression of frequently recurring genital herpes simplex virus infection. A multicenter double-blind trial. JAMA 1988;260:201-6.

66. Baker DA, Blythe JG, Kaufman R, et al. One-year suppression of frequent recurrences of genital herpes with oral acyclovir. Obstet Gynecol 1989;73:84-7.

67. Kroon S, Petersen CS, Andersen LP, et al. Oral acyclovir suppressive therapy in severe recurrent genital herpes. A doubleblind, placebo-controlled cross-over study. Danish Med Bulletin 1989;36:298-300.
68. Mostow SR, Mayfield JL, Marr JJ, et al. Suppression of recurrent genital herpes by single daily dosages of acyclovir. The Wellcome International Antiviral Symposium. Am J Med 1988;85(2A):30-33.

69. Reitano M, Tyring S, Lang W, et al. Valaciclovir for the suppression of recurrent genital herpes simplex virus infection: a large-scale dose range-finding study. J Infect Dis 1998;178:603-10.

70. Goldberg LH, Kaufman R, Kurtz TO, et al. Long-term suppression of recurrent genital herpes with acyclovir. Arch Dermatol 1993;129:582-7.

71. Mindel A, Carney O, Freris AA, et al. Dosage and safety of longterm suppressive acyclovir therapy for recurrent genital herpes. Lancet 1988;i:926-8.

72. Nusinoff Lehrman S, Douglas JM, Corey L, et al. Recurrent genital herpes and suppressive oral acyclovir therapy. Ann Intern Med 1986;104:786-90.

73. Mertz GJ, Loveless MO, Levin MJ, et al. Oral famciclovir for suppression of recurrent genital herpes simplex virus infection in women. Arch Intern Med 1997;157:343-9.

74. Diaz-Mitoma F, Sibbald GR, Shafran SD, et al. Oral famciclovir for the suppression of recurrent genital herpes. A randomized controlled trial. JAMA 1998;280:887-92.

75. Patel R, Bodworth NJ, Woolley P, et al. Valaciclovir for the suppression of recurrent genital HSV infection: a placebo controlled study of once daily therapy. Genitourin Med 1997;73:105-9.

76. Stray-Pedersen B. Acyclovir in late pregnancy to prevent neonatal herpes simplex. Lancet 1990;336:756.

77. Scott L, Sanchez PJ, Jackson GL, et al. Acyclovir suppression to prevent cesarean delivery after first-episode genital herpes. Obstet Gynecol 1996;87:69-73.

78. Wald A, Zeh J, Barnum G, et al. Suppression of subclinical shedding of herpes simplex virus Type 2 with acyclovir. Ann Intern Med 1996;124:8-15

79. Carney O, Ross E, Ikkos G, Mindel A. The effect of suppressive oral acyclovir on the psychological morbidity associated with recurrent genital herpes. Genitourin Med 1993;69:457-9.

80. Rompalo AM, Mertz GJ, Davis LG, et al. Oral acyclovir for treatment of first-episode herpes simplex virus proctitis. JAMA 1988;259:2879-81. 
In the Original Article "Guidance on patient identification and administration of recombinant human activated protein $\mathrm{C}$ for the treatment of severe sepsis" published in the November/December issue of The Canadian Journal of Infectious Diseases on pages 361 to 372 Figure 2 on page 365 was printed as an incomplete figure. Please see the next page for the complete figure.

In the Original Article "Distribution of serogroups of Neisseria meningitidis and antigenic characterization of serogroup Y memingococci in Canada, January 1, 1999 to June 30, 2001" published in the November/December issue of The Canadian Journal of Infectious Diseases on pages 391 to 396 a mistake appeared in the Results section on page 392 . The mistake relates to the sentence (column 2, paragraph 1, line 10) "This molecular method identified two isolates as serogroup B, two as serogroup Y and one each as serogroups C and W135". The sentence should read "This molecular method identified four isolates as serogroup B, one as serogroup C and two each as serogroups Y and W135".

The authors for the CIDS Position Paper "Contemporary antiviral drug regimens for the prevention and treatment of orolabial and anogenital herpes simplex virus infection in the normal host: Four approved indications and 13 off-label uses” published in the January/February issue of The Canadian Journal of Infectious Diseases on pages 17 to 27 should have been printed as: Fred Y Aoki MD, for the CIDS Antimicrobial Agents Committee. The paper originated from the Committee. The Committee members involved were:

Gerald A Evans, Kingston, Ontario (Chair)

Susan King, Toronto, Ontario

Michel Laverdiere, Montreal, Quebec

Lindsay Nicolle, Winnipeg, Manitoba

Peter Phillips, Vancouver, British Columbia

Corinna Quan, Windsor, Ontario

Coleman Rotsteiin, Hamilton, Ontario 


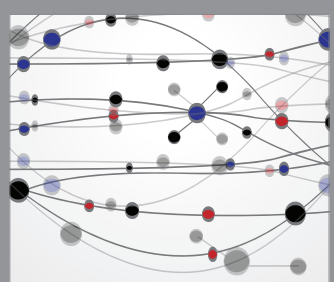

The Scientific World Journal
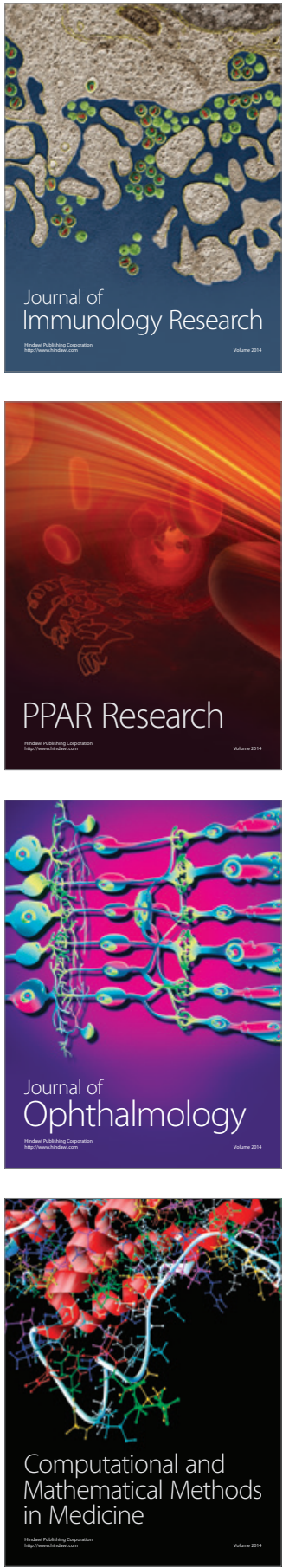

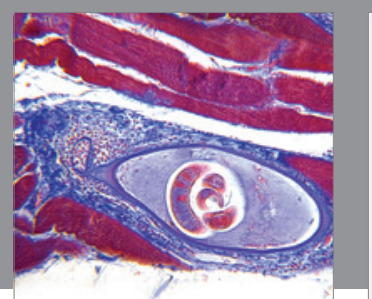

Gastroenterology Research and Practice

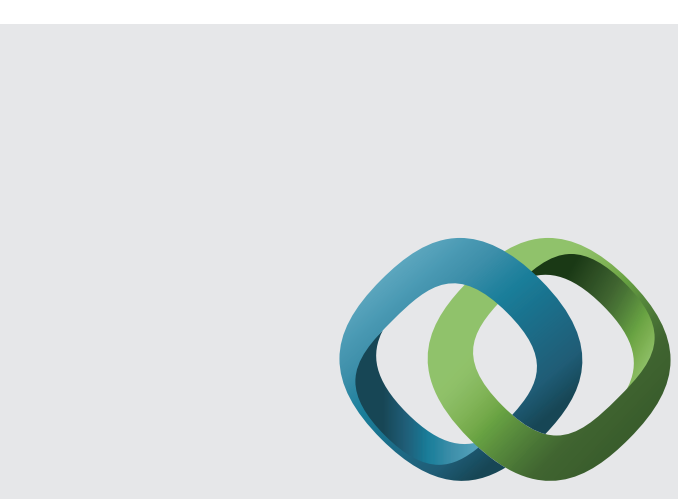

\section{Hindawi}

Submit your manuscripts at

http://www.hindawi.com
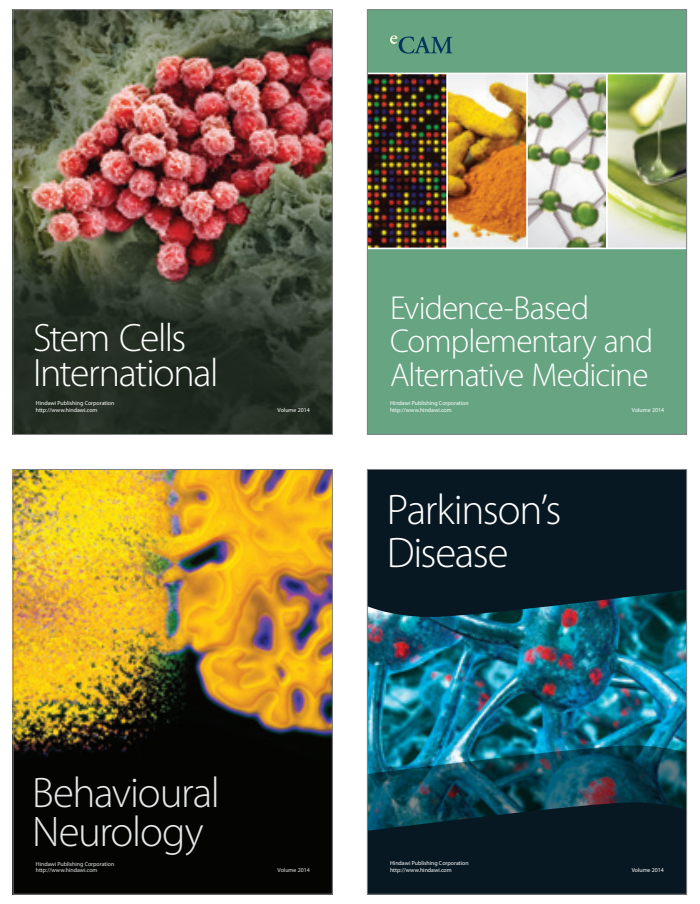
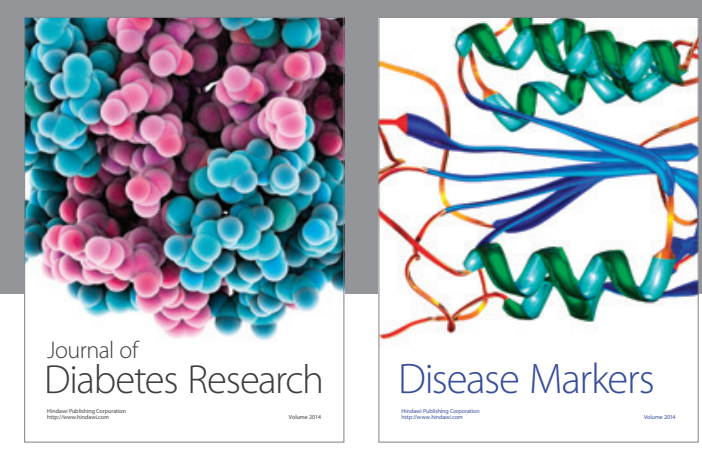

Disease Markers
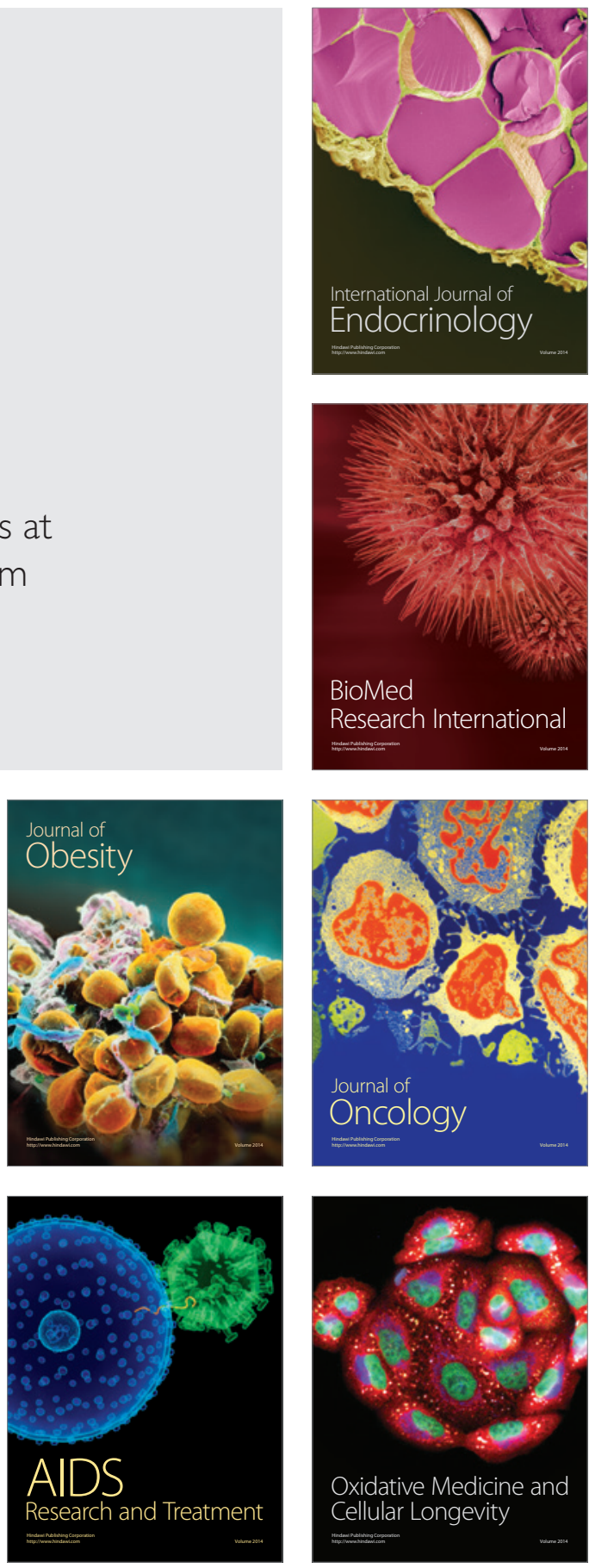